\title{
Antiquity of Shorebird Acoustic Displays
}

Author(s) :Edward H. Miller and Allan J. Baker

Source: The Auk, 126(2):454-459. 2009.

Published By: The American Ornithologists' Union

URL: http://www.bioone.org/doi/full/10.1525/auk.2009.2409.2

BioOne (www.bioone.org) is a nonprofit, online aggregation of core research in the biological, ecological, and environmental sciences. BioOne provides a sustainable online platform for over 170 journals and books published by nonprofit societies, associations, museums, institutions, and presses.

Your use of this PDF, the BioOne Web site, and all posted and associated content indicates your acceptance of BioOne's Terms of Use, available at www.bioone.org/page/terms of use.

Usage of BioOne content is strictly limited to personal, educational, and non-commercial use. Commercial inquiries or rights and permissions requests should be directed to the individual publisher as copyright holder. 
The Auk 126(2):454-459, 2009

(c) The American Ornithologists' Union, 2009 Printed in USA.

Antiquity of Shorebird Acoustic Displays.-Bird vocalizations invariably diverge between allopatric populations because of social selection, cultural evolution, and adaptation to different environments (Seddon 2005, Ritchie 2007, Price 2008). As a consequence, vocal differences between populations are invaluable in low-level systematic treatments and descriptions of new species (Connors et al. 1993, Kennedy et al. 2001, Allen et al. 2004). Paradoxically, however, considerable phylogenetic signal also can be present in vocalizations (Lanyon 1969, Payne 1986, Farnsworth and Lovette 2008). Therefore, at least some vocal traits in at least some clades must evolve fairly slowly. We describe a possible example of extremely slow evolution of acoustic displays in shore birds (Charadrii and Scolopaci). We conclude that many shorebird sounds and sound traits are tens of millions of years old, and some may even date to the Cretaceous.
The Charadriiformes arose in the Cretaceous $>90$ mya, and multiple later divergences took place within both Charadrii and Scolopaci in the Cretaceous and Tertiary (Paton et al. 2003, Paton and Baker 2006, Baker et al. 2007, Tavares and Baker 2008; Fig. 1). Shorebirds are attractive for investigating rates of evolutionary change in vocal displays for several reasons: their vocalizations are not learned and so are not subject to short-term cultural evolution as occurs in songbirds; vocalizations show little to no geographic variation within species (Miller et al. 1983, Miller 1986); complex loud vocalizations, and repertoires composed of discrete sound classes, occur in many species (Miller 1984, 1996a); and wellresolved phylogenies with divergence times are available (Paton et al. 2003, Buehler and Baker 2005, Pereira and Baker 2005, Paton and Baker 2006, Baker et al. 2007, Tavares and Baker 2008).

Materials and methods.-Samples and techniques are described by Paton et al. (2003), Buehler and Baker (2005), Pereira and Baker (2005), Paton and Baker (2006), Baker et al. (2007), and Tavares and Baker (2008). Homology reasoning for acoustic displays and other forms of behavior is the same as for other kinds of traits ("Behavior is not special, it is only more difficult to characterize"-Wenzel 1992:361; Greene 1994). However, display homologies are assessed, in part, on the basis of behavioral function and context, in addition to structural display traits (Wenzel 1992). For example, many acoustic signals of birds are integrated with optical display elements, and all displays are accompanied by extra-display sources of information such as social context, social or physical characteristics of sender or receiver, and the physical location of displays (Smith 1977, 1997; Miller 1984). These "contextual" properties of displays are used routinely in homology reasoning and reduce the possibility that similar displays are convergences (Wenzel 1992). For example, parental adult turnstones (Arenaria spp.) and calidridine sandpipers with chicks utter "alarm" trills when approached by a human observer (or other terrestrial predator): physical properties of the trill, characteristics of calling birds (i.e., parental adults with chicks), and the specific circumstances in

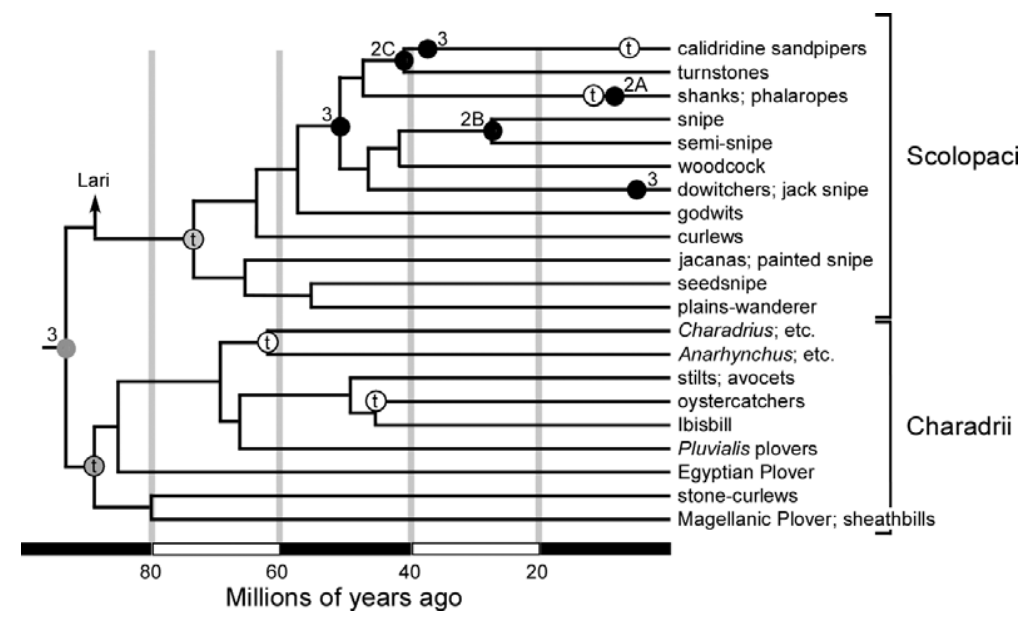

FIG. 1. Partial phylogeny of the Charadriiformes (excluding Lari: gulls, terns, and auks), indicating examples of homologous acoustic displays discussed in the text or shown in Figures 2 and 3. Strong homologies: black dots, examples with spectrograms (figure numbers are indicated); outlined dots with " $\mathrm{t}$ ", text examples only (i.e., no spectrograms). Possible homologies: gray dots, with spectrograms or as text examples only (" $\mathrm{t}$ "), as above. After Baker et al. (2007, fig. 2). 

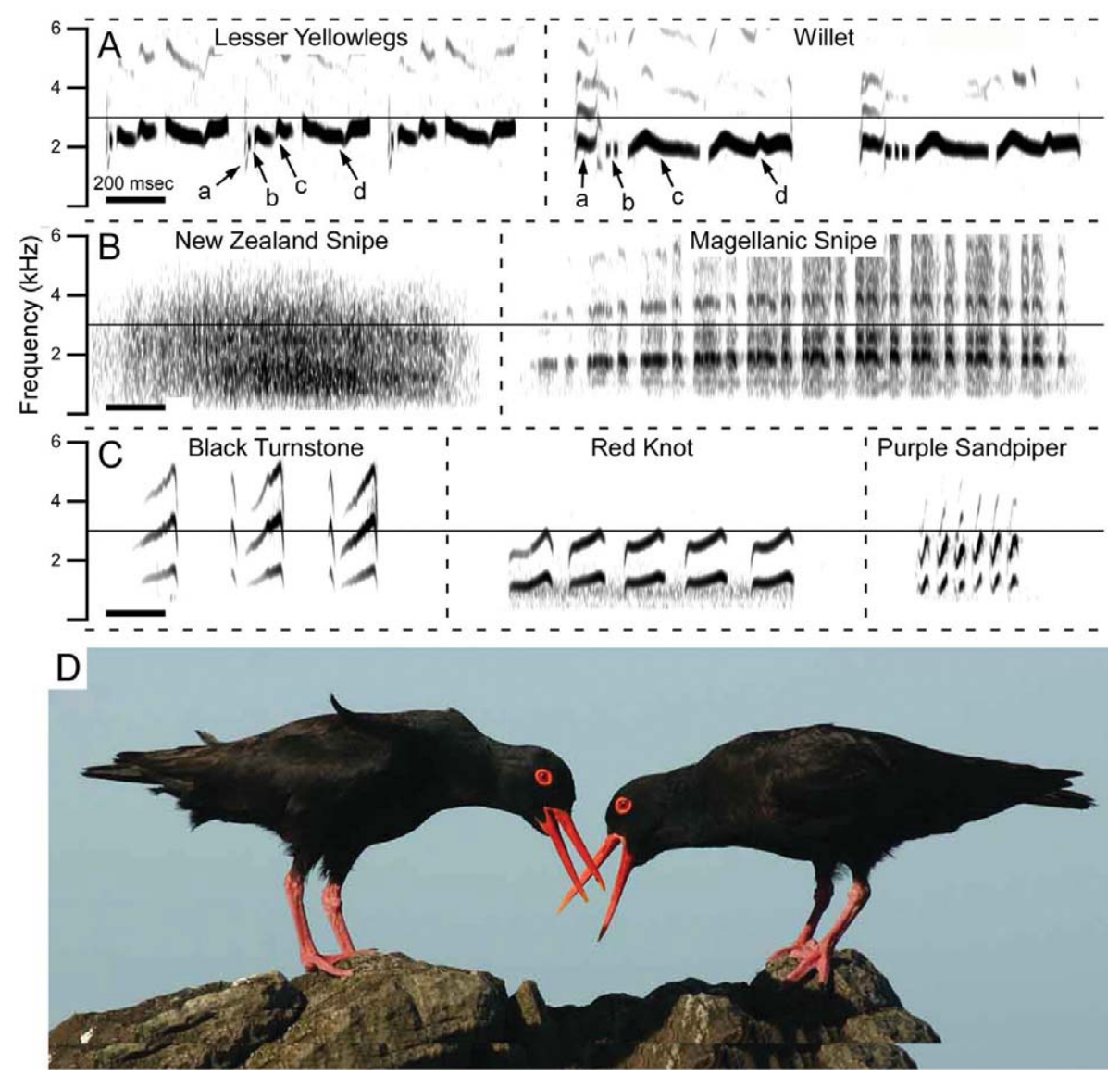

FiG. 2. (A) Spectrograms of rhythmically repeated calls in male aerial nuptial display of Lesser Yellowlegs (three calls) and Willet (two calls). The 3-kHz level is included as a visual guide. Each repeated call begins with a brief harmonically rich element (a), followed by one-to-several brief harmonically weaker elements (b), and then two longer, high-amplitude, frequency-modulated elements (c, d). (B) Spectrograms of sounds produced by specialized rectrices during dives in male aerial nuptial flight display of Chatham Island Snipe (vocal display components omitted) and Magellanic Snipe. (C) Spectrograms of "alarm" trills of parental Black Turnstone, Red Knot, and Purple Sandpiper. (D) Piping display of African Black Oystercatcher (Haematopus moquini; photograph by J. Walton).

which the call is uttered, can be used together to infer that this call type is homologous throughout the sandpiper-turnstone clade.

The spectrograms presented here are from the following sources: Lesser Yellowlegs (Tringa flavipes) and Short-billed Dowitcher (Limnodromus griseus), northwestern British Columbia, May 1983, E.H.M.; Willet (Tringa semipalmata) and Piping Plover (Charadrius melodus), Saskatchewan, June 2003, E.H.M.; Chatham Island Snipe (Coenocorypha pusilla), Chatham Islands, New Zealand, September 1984, C. M. Miskelly; Magellanic Snipe (Gallinago paraguaiae magellanica), southern Chile, November 2004, E.H.M.; Black Turnstone (Arenaria melanocephala), Yukon-Kuskokwim Delta, Alaska, May 1980, C. M. Handel; Red Knot (Calidris canutus), Ellesmere Island, Canada, July 1972, W. W. H. Gunn; Purple Sandpiper (C. maritima), Iceland, May 1989, E.H.M.; Long-billed Dowitcher (L. scolopaceus), northern Yakutia, Russia, June 1976, B. N. Veprintsev and V. V. Leonovitch; Least Sandpiper (C. minutilla), northern Manitoba, June 1978, E.H.M.; and Great Knot (C. tenuirostris), eastern Chukotka, Russia, June 1995, P. S. Tomkovich. Spectrograms were prepared using RAVEN, version 1.3 (Cornell Lab of Ornithology, Ithaca, New York).
Results.-Short-billed and Long-billed dowitchers diverged from one another $\sim 4$ mya (Avise and Zink 1988), but their vocal repertoires and even nuptial songs are very similar (Miller et al. 1983, 1984). The same is true of vocalizations in the clade of Dunlin (C. alpina) plus Rock Sandpiper (C. ptilocnemis) and Purple Sandpiper (Miller 1996a, Warnock and Gill 1996, Gill et al. 2002, Payne and Pierce 2002); the latter two species separated $\sim 6$ mya (A. Baker unpubl. data). The sister species Willet and Lesser Yellowlegs separated $~ 8.5$ mya (Pereira and Baker 2005). Their vocal repertoires include nuptial flight-display calls of males that are very similar between the two species (Douglas 1998, Tibbitts and Moskoff 1999, Lowther et al. 2001; Fig. 2A). Finally, the vocal repertoire and acoustic structure of calls in the breeding period are very similar between the sister species Green Sandpiper (Tringa ochropus) and Solitary Sandpiper (T. solitaria), which diverged from one another $\sim 11.5$ mya (Oring 1968, Pereira and Baker 2005, Tavares and Baker 2008).

Even more conservative evolution is apparent in other clades. Semi-snipe plus snipe arose as a clade 27 mya (Baker et al. 2007). Except for the ground-lekking Great Snipe (G. media; Ferdinand 


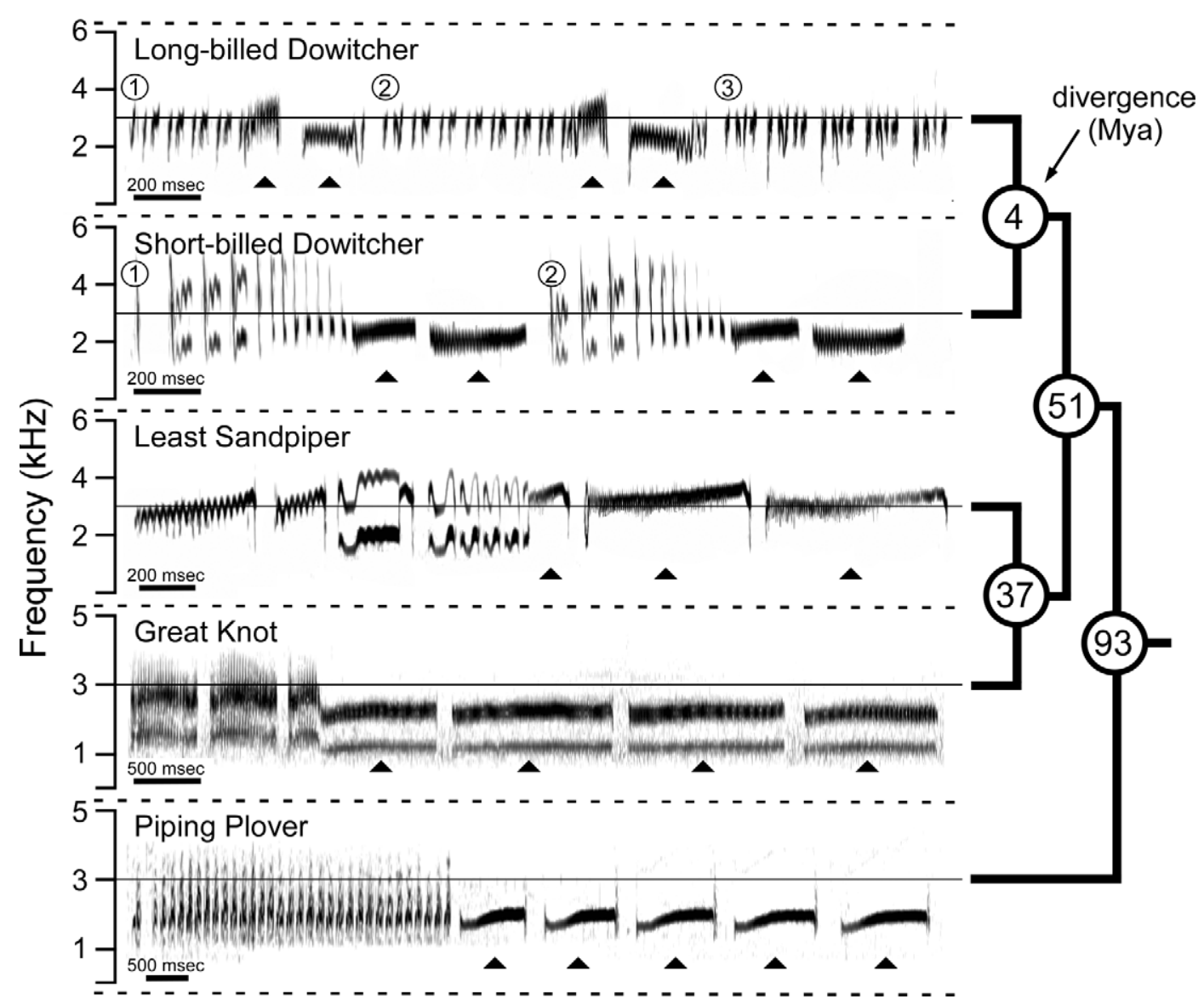

FIG. 3. Shorebird song organization may be extremely ancient. Examples of nuptial aerial songs by males are shown for Long-billed and Short-billed dowitchers, Least Sandpiper, Great Knot, and Piping Plover. The 3-kHz level is included as a visual guide. Songs in all species are characterized by an introductory series of sound elements—one (e.g., Piping Plover) to several (e.g., Least Sandpiper)_followed by several repetitions of long frequencymodulated (pulsed) elements (marked by triangles; the elements are not pulsed in Piping Plover). Songs are often repeated (for Long-billed Dowitcher, " 1 " and "2" mark repeated song units and "3" marks a terminal extended series of elements; for Short-billed Dowitcher, " 1 " and " 2 " mark repeated song units). Divergence times are from Baker et al. (2007) and A. J. Baker (unpubl. data).

1966, Lemnell 1978), males of all species in this clade produce nonvocal drumming sounds in display dives (Tuck 1972; Reddig 1978; Sutton 1981; Miskelly 1987, 1990, 2005; Miskelly et al. 2006; Fig. 2B). Within the Scolopacidae, turnstones and calidridines diverged from one another $\sim 41$ mya (Baker et al. 2007) but share many vocal classes, ranging from male flight-display calls to parental "alarm" trills (Fig. 2C; Cramp 1983; Miller 1984, 1985, 1996a; Handel and Gill 2001; Johnson et al. 2008). All oystercatchers (Haematopodidae; 11 extant species) possess a complex communal display ("piping") that involves striking postures, movements, and lengthy vocalizations with similar syntactical organization across species (Fig. 2D; Miller and Baker 1980, Cramp 1983, Marchant and Higgins 1993, Hockey 1996). The piping display dates to at least 36-45 mya, when oystercatchers diverged from the lineage leading to the Ibisbill (Ibidorhyncha struthersii; Baker et al. 2007), and it may be even older (see below).

Calidridine sandpipers and dowitchers last shared a common ancestor $\sim 51$ mya (Baker et al. 2007), but the complex nuptial song of both dowitcher species is extremely similar to that of several calidridines (e.g., Least Sandpiper, Great Knot, Surfbird [Aphriza virgata]) over multiple structural scales: number of song-element types within songs, acoustic structure of song-element types, and syntactical arrangement of song elements (Miller 1983a, 1996a; Miller et al. 1983, 1984, 1987; Fig. 3). Finally, likely homologous call types are shared by plovers of the genus Charadrius and by the New Zealand endemic Wrybill (Anarhynchus frontalis; Phillips 1980, Sung et al. 2005), which last shared a common ancestor 62 mya (Baker et al. 2007).

Some striking acoustic similarities occur between even more distantly related groups. Resemblances to the oystercatcher piping display are seen in group displays in related lineages: stilts and avocets (Recurvirostridae; divergence $\sim 49$ mya) and the more distantly related Magellanic Plover (Pluvianellus socialis) and stonecurlews (Burhinidae; divergence 89 mya; Jehl 1975, Cramp 1983, Marchant and Higgins 1993, Hume 1996, Baker et al. 2007). Males in many distantly separated species terminate their nuptial aerial displays with a complex vocalization ("song") during descent or upon landing, including snipe, plovers of the genera Charadrius and Pluvialis, calidridines and turnstones, seedsnipe (Thinocoridae), and others (Miller 1984, 1996a, b; Byrkjedal and Thompson 
1998; Sung et al. 2005). Ground advertisement calls of male seedsnipe are similar in structure and organization to some calls of semi-snipe and snipe (Miller 1996b); these two clades last shared a common ancestor $\sim 73$ mya (Baker et al. 2007). Finally, song complexity and organization of nuptial song in some Charadrius spp. is very similar to song of dowitchers and some calidridines (Fig. 3); if this represents homology, its origin was at least $~ 93$ mya (Baker et al. 2007). We therefore suggest that acoustic displays of shorebirds express much evolutionary conservatism and are tens of millions of years old; even change in sexually selected displays has been confined within highly conserved sound classes.

Discussion.-Charadriiformes lack vocal learning, and most have a morphologically simple vocal tract (Warner 1969, King 1989, Brown and Ward 1990, Miller et al. 2008). Nevertheless, some species have structurally complex vocalizations (Miller 1983b, Miller et al. 1988), and others have morphological specializations for voice production (Wood-Mason 1878, Beddard 1901, Niethammer 1966, Kishchinskii 1974, Kirwan 1996, Fitch 1999). Therefore, neither the absence of learning nor anatomy sets tight constraints on evolutionary change in voice or voice production, so neither can account for the conservatism we describe (Bass et al. 2008). In any event, conservatism is not limited to vocal sounds, but occurs also in nonvocal sounds, and in optical displays like the oystercatcher piping display. Display conservatism may be more widespread in animals than conventionally thought. For example, Moynihan (1975) pointed out that homologous displays in Primates and Carnivora must have appeared no later than the common ancestors of those groups ( $\sim 80$ mya for Carnivora; Murphy et al. 2007), and the three major modes of sound production in insects appeared by 230 mya (Hoch et al. 2006). Therefore, both particular and general explanations for conservatism should be sought (e.g., highly conserved programs for vocal control or sensory processing; Bass et al. 2008, Neuhofer et al. 2008).

Research on several fronts could advance our understanding of conservative display evolution in shorebirds. At a basic level, assessment of ancient homologies is hampered by uneven knowledge of acoustic repertoires, acoustic structure, and display behavior (Greene 1994). Information on displays of ancient clades like that comprising stone-curlews, sheathbills, and the Magellanic Plover should be particularly informative (see remarks about group displays above). We feel that increased attention should be given to non-sexually selected displays like brood-attendance and "alarm" calls, and calls of chicks, because these evolve more slowly than sexually selected displays (Marler 1957). Finally, vocal-tract anatomy has been described for very few shorebirds, mechanisms of voice production have not been studied, and neurobiology and hearing are essentially unstudied (Pettigrew and Larsen 1990).

The first acoustic communication signals in air were produced by insects, and these formed the biological soundscape of Permian moss forests (Hoch et al. 2006). We believe that further research on shorebirds could reveal acoustic homologies dating back to the later part of the age of dinosaurs. We acknowledge that this prediction is based on molecular estimates and that paleontological estimates of divergence times are more conservative. Nevertheless, if molecular estimates are accurate, sounds similar to those of extant shorebirds contributed to the biological soundscape $>65$ mya. These sounds would have been audible to most dinosaurs: the frequency of extant shorebird sounds is within the inferred hearing range of small to medium-sized dinosaurs, and lower frequencies (to $\sim 3 \mathrm{kHz}$ ) would have been audible to large forms (Gleich et al. 2005). Despite the demise of dinosaurs, a part of their acoustic environment may live on in their extant bird relatives.

Acknowledgments.-We thank the late W. W. H. Gunn, C. M. Handel, C. M. Miskelly, P. S. Tomkovich, and the late B. N. Veprintsev for sharing their recordings with us. The photograph of African Black Oystercatchers was provided by J. Walton. We thank L. Desutter-Grandcolas, D. E. Innes, and T. Robillard for comments and V. Bogdanova for help with translation. Our research was funded by the Natural Sciences and Engineering Research Council of Canada.-EDwARd H. Miller, Department of Biology, Memorial University, St. John's, Newfoundland and Labrador A1B 3X9, Canada (e-mail: tmiller@mun.ca); and AlLAN J. BAKER, Department of Natural History, Royal Ontario Museum, Toronto, Ontario M5S 2C6, Canada.

\section{Literature Cited}

Allen, D., C. Oliveros, C. Española, G. Broad, and J. C. T. Gonzalez. 2004. A new species of Gallirallus from Calayan Island, Philippines. Forktail 20:1-7.

Avise, J. C., AND R. M. ZINK. 1988. Molecular genetic divergence between avian sibling species: King and Clapper rails, Long-billed and Short-billed dowitchers, Boat-tailed and Great-tailed grackles, and Tufted and Black-crested titmice. Auk 105:516-528.

Baker, A. J., S. L. Pereira, and T. A. Paton. 2007. Phylogenetic relationships and divergence times of Charadriiformes genera: Multigene evidence for the Cretaceous origin of at least 14 clades of shorebirds. Biology Letters 3:205-209.

BAss, A. H., E. H. Gilland, ANd R. BAKER. 2008. Evolutionary origins for social vocalization in a vertebrate hindbrain-spinal compartment. Science 321:417-421.

BEDDARD, F. E. 1901. Notes upon the anatomy and systematic position of Rhynchaea. Proceedings of the Zoological Society of London 1901:587-596.

BROwn, C., AND D. WARD. 1990. The morphology of the syrinx in the Charadriiformes (Aves): Possible phylogenetic implications. Bonner Zoologische Beiträge 41:95-107.

Buehler, D. M., AND A. J. BAKer. 2005. Population divergence times and historical demography in Red Knots and Dunlins. Condor 107:497-513.

Byrkjedal, I., And D. Thompson. 1998. Tundra Plovers: The Eurasian, Pacific and American Golden Plovers and Grey Plover. Princeton University Press, Princeton, New Jersey.

Connors, P. G., B. J. McCaffery, ANd J. L. Maron. 1993. Speciation in golden-plovers, Pluvialis dominica and P. fulva: Evidence from the breeding grounds. Auk 110:9-20.

Cramp, S., Ed. 1983. Handbook of the Birds of Europe, the Middle East and North Africa: The Birds of the Western Palearctic, vol. 3: Waders to Gulls. Oxford University Press, Oxford, United Kingdom.

Douglas, H. D., III. 1998. Response of eastern willets (Catoptrophorus s. semipalmatus) to vocalizations of eastern and western (C. s. inornatus) willets. Auk 115:514-518.

FARNSWORTH, A., AND I. J. LovetTe. 2008. Phylogenetic and ecological effects on interspecific variation in structurally simple avian vocalizations. Biological Journal of the Linnean Society 94:155-173. 
FerdinAnd, L. 1966. Display of the Great Snipe (Gallinago media Latham). Dansk Ornithologisk Forening, Copenhagen Tidsskrift 60:14-34.

FiтcH, W. T. 1999. Acoustic exaggeration of size in birds via tracheal elongation: Comparative and theoretical analyses. Journal of Zoology 248:31-48.

Gill, R. E., P. S. Tomkovich, And B. J. MCCAffery. 2002. Rock Sandpiper (Calidris ptilocnemis). In The Birds of North America, no. 686 (A. Poole and F. Gill, Eds.). Birds of North America, Philadelphia.

Gleich, O., R. J. Dooling, And G. A. Manley. 2005. Audiogram, body mass, and basilar papilla length: Correlations in birds and predictions for extinct archosaurs. Naturwissenschaften 92:595598.

Greene, H. W. 1994. Homology and behavioral repertoires. Pages 369-391 in Homology: The Hierarchical Basis of Comparative Biology (B. K. Hall, Ed.). Academic Press, San Diego, California.

Handel, C. M., And R. E. Gill. 2001. Black Turnstone (Arenaria melanocephala). In The Birds of North America, no. 585 (A. Poole and F. Gill, Eds.). Birds of North America, Philadelphia.

Hoch, H., J. DeCKeRT, AND A. WESSEL. 2006. Vibrational signalling in a Gondwanan relict insect (Hemiptera: Coleorrhyncha: Peloridiidae). Biology Letters 2:222-224.

Hockey, P. A. R. 1996. Family Haematopodidae (oystercatchers). Pages 308-325 in Handbook of the Birds of the World, vol. 3: Hoatzin to Auks (J. del Hoyo, A. Elliott, and J. Sargatal, Eds.). Lynx Edicions, Barcelona, Spain.

Hume, R. A. 1996. Family Burhinidae (thick-knees). Pages 348-363 in Handbook of the Birds of the World, vol. 3: Hoatzin to Auks (J. del Hoyo, A. Elliott, and J. Sargatal, Eds.). Lynx Edicions, Barcelona, Spain.

JEHL, J. R., JR. 1975. Pluvianellus socialis: Biology, ecology, and relationships of an enigmatic Patagonian shorebird. Transactions of the San Diego Society of Natural History 18:25-74.

Johnson, M., S. Aref, And J. R. WAlters. 2008. Parent-offspring communication in the Western Sandpiper. Behavioral Ecology 19:489-501.

Kennedy, R. S., T. H. Fisher, S. C. B. Harrap, A. C. Diesmos, And A. S. Manamtam. 2001. A new species of woodcock (Aves: Scolopacidae) from the Philippines and a re-evaluation of other Asian/Papuasian woodock. Forktail 17:1-12.

KING, A. S. 1989. Functional anatomy of the syrinx. Pages 105-192 in Form and Function in Birds, vol. 4 (A. S. King and J. McLelland, Eds.). Academic Press, London.

Kirwan, G. M. 1996. Family Rostratulidae (painted-snipes). Pages 292-301 in Handbook of the Birds of the World, vol. 3: Hoatzin to Auks (J. del Hoyo, A. Elliott, and J. Sargatal, Eds.). Lynx Edicions Barcelona, Spain.

KISHCHINSKII, V. 1974. Biology and behavior of the Pectoral Sandpiper in the east Siberian tundra. [In Russian.] Byulleten' Moskovskoho Obshchestva Ispytatelei Prirody, Otdel Biologicheskii 79:73-88.

LANYON, W. E. 1969. Vocal characters and avian systematics. Pages 291-310 in Bird Vocalizations: Their Relation to Current Problems in Biology and Psychology (R. A. Hinde, Ed.). Cambridge University Press, Cambridge, United Kingdom.

Lemnell, P. A. 1978. Social behaviour of the Great Snipe Capella media at the arena display. Ornis Scandinavica 9:146-163.
Lowther, P. E., H. D. Douglas III, and C. L. Gratto-Trevor. 2001. Willet (Catoptrophorus semipalmatus). In The Birds of North America, no. 579 (A. Poole and F. Gill, Eds.). Birds of North America, Philadelphia.

Marchant, S., and P. J. Higgins, Eds. 1993. Handbook of Australian, New Zealand and Antarctic Birds, vol. 2: Raptors to Lapwings. Oxford University Press, Melbourne, Australia.

MARLER, P. 1957. Specific distinctiveness in the communication signals of birds. Behaviour 11:13-39.

Miller, E. H. 1983a. Structure of display flights in the Least Sandpiper. Condor 85:220-242.

Miller, E. H. 1983b. The structure of aerial displays in three species of Calidridinae (Scolopacidae). Auk 100:440-451.

Miller, E. H. 1984. Communication in breeding shorebirds. Pages 169-241 in Shorebirds: Breeding Behavior and Populations (J. Burger and B. L. Olla, Eds.). Plenum Press, New York.

Miller, E. H. 1985. Parental behavior in the Least Sandpiper (Calidris minutilla). Canadian Journal of Zoology 63:1593-1601.

Miller, E. H. 1986. Components of variation in nuptial calls of the Least Sandpiper (Calidris minutilla; Aves, Scolopacidae). Systematic Zoology 35:400-413.

Miller, E. H. 1996a. Acoustic differentiation and speciation in shorebirds. Pages 241-257 in Ecology and Evolution of Acoustic Communication in Birds (D. E. Kroodsma and E. H. Miller, Eds.). Cornell University Press, Ithaca, New York.

Miller, E. H. 1996b. Nuptial vocalizations of male Least Seedsnipe: Structure and evolutionary significance. Condor 98:418-422.

Miller, E. H., AND A. J. BAKer. 1980. Displays of the Magellanic Oystercatcher (Haematopus leucopodus). Wilson Bulletin 92:149-168.

Miller, E. H., W. W. H. GunN, And R. E. Harris. 1983. Geographic variation in the aerial song of the Short-billed Dowitcher (Aves, Scolopacidae). Canadian Journal of Zoology 61:21912198.

Miller, E. H., W. W. H. Gunn, and S. F. MaClean, Jr. 1987. Breeding vocalizations of the Surfbird. Condor 89:406-412.

Miller, E. H., W. W. H. GunN, J. P. Myers, and B. N. VeprintSEV. 1984. Species-distinctiveness of Long-billed Dowitcher song (Aves: Scolopacidae). Proceedings of the Biological Society of Washington 97:804-811.

Miller, E. H., W. W. H. Gunn, and B. N. Veprintsev. 1988. Breeding vocalizations of Baird's Sandpiper Calidris bairdii and related species, with remarks on phylogeny and adaptation. Ornis Scandinavica 19:257-267.

Miller, E. H., S. S. Seneviratne, I. L. Jones, G. J. Robertson, AND S. I. Wilhelm. 2008. Syringeal anatomy and allometry in murres (Alcidae: Uria). Journal of Ornithology 149:545-554.

Miskelly, C. M. 1987. The identity of the Hakawai. Notornis 34: 95-116.

Miskelly, C. M. 1990. Aerial displaying and flying ability of Chatham Island Snipe Coenocorypha pusilla and New Zealand Snipe C. aucklandica. Emu 90:28-32.

Miskelly, C. M. 2005. Evidence for 'hakawai' aerial displaying by Snares Island Snipe (Coenocorypha aucklandica huegeli). Notornis 52:163-165.

Miskelly, C. M., E. A. Bell, G. P. Elliott, and K. J. Walker. 2006. 'Hakawai' aerial displaying by three populations of subantarctic snipe (genus Coenocorypha). Notornis 53:375-381. 
Moynihan, M. 1975. Conservatism of displays and comparable stereotyped patterns among cephalopods. Pages 276-291 in Function and Evolution in Behaviour: Essays in Honour of Professor Niko Tinbergen, F.R.S. (G. Baerends, C. Beer, and A. Manning, Eds.). Clarendon Press, Oxford, United Kingdom.

Murphy, W. J., T. H. Pringle, T. A. Crider, M. S. Springer, and W. MilLER. 2007. Using genomic data to unravel the root of the placental mammal phylogeny. Genome Research 17:413-421.

Neuhofer, D., S. Wohlgemuth, A. Stumpner, and B. RONACHER. 2008. Evolutionarily conserved coding properties of auditory neurons across grasshopper species. Proceedings of the Royal Society of London, Series B 275:1965-1974.

Niethammer, G. 1966. Sexualdimorphismus am Ösophagus von Rostratula. Journal of Ornithology 107:201-204.

Oring, L. W. 1968. Vocalizations of the Green and Solitary sandpipers. Wilson Bulletin 80:395-420.

Paton, T. A., AND A. J. BAKer. 2006. Sequences from 14 mitochondrial genes provide a well-supported phylogeny of the charadriiform birds congruent with the nuclear RAG-1 tree. Molecular Phylogenetics and Evolution 39:657-667.

Paton, T. A., A. J. Baker, J. G. Groth, and G. F. BarrowClough. 2003. RAG-1 sequences resolve phylogenetic relationships within charadriiform birds. Molecular Phylogenetics and Evolution 29:268-278

Payne, L. X., And E. P. Pierce. 2002. Purple Sandpiper (Calidris maritima). In The Birds of North America, no. 706 (A. Poole and F. Gill, Eds.). Birds of North America, Philadelphia.

Payne, R. B. 1986. Bird songs and avian systematics. Pages $87-126$ in Current Ornithology, vol. 3 (R. F. Johnston, Ed.). Plenum Press, New York.

Pereira, S. L., ANd A. J. BAKer. 2005. Multiple gene evidence for parallel evolution and retention of ancestral morphological states in the shanks (Charadriiformes: Scolopacidae). Condor 107:514-526.

Pettigrew, J. D., And O. N. Larsen. 1990. Directional hearing in the Plains-wanderer, Pedionomus torquatus. Pages 179-190 in Information Processing in Mammalian Auditory and Tactile Systems (M. Rowe and L. Aitkin, Eds.). Alan R. Liss, New York.

Phillips, R. E. 1980. Behaviour and systematics of New Zealand plovers. Emu 80:177-197.

Price, T. 2008. Speciation in Birds. Roberts, Greenwood Village, Colorado.
RedDig, E. 1978. Der Ausdrucksflug der Bekassine (Capella gallinago gallinago). Journal für Ornithologie 119:357-387.

Ritchie, M. G. 2007. Sexual selection and speciation. Annual Review of Ecology, Evolution, and Systematics 38:79-102.

SEDDON, N. 2005. Ecological adaptation and species recognition drives vocal evolution in Neotropical suboscine birds. Evolution 59:200-215.

Smith, W. J. 1977. The Behavior of Communicating: An Ethological Approach. Harvard University Press, Cambridge, Massachusetts.

Sмiтh, W. J. 1997. The behavior of communicating, after twenty years. Pages 7-53 in Perspectives in Ethology, vol. 12: Communication (D. H. Owings, M. D. Beecher and N. S. Thompson, Eds.). Plenum Press, New York.

Sung, H.-C., E. H. Miller, And S. P. Flemming. 2005. Breeding vocalizations of the Piping Plover (Charadrius melodus): Structure, diversity, and repertoire organization. Canadian Journal of Zoology 83:579-595.

Sutton, G. M. 1981. On aerial and ground displays of the world's snipes. Wilson Bulletin 93:457-477.

TAVARES, E. S., AND A. J. BAKER. 2008. Single mitochondrial gene barcodes reliably identify sister-species in diverse clades of birds. BMC Evolutionary Biology 8:81.

Tibвitts, T. L., AND W. Moskoff. 1999. Lesser Yellowlegs (Tringa flavipes). In The Birds of North America, no. 427 (A. Poole and F. Gill, Eds.). Birds of North America, Philadelphia.

Tuck, L. M. 1972. The Snipes: A Study of the Genus Capella. Canadian Wildlife Service Monograph Series, no. 5.

Warner, R. W. 1969. The Anatomy of the Avian Syrinx. Ph.D. dissertation, University of London, London.

Warnock, N. D., AND R. E. GILl. 1996. Dunlin (Calidris alpina). In The Birds of North America, no. 203 (A. Poole and F. Gill, Eds.). Academy of Natural Sciences, Philadelphia, and American Ornithologists' Union, Washington, D.C.

WeNZEL, J. W. 1992. Behavioral homology and phylogeny. Annual Review of Ecology and Systematics 23:361-381.

Wood-MAson, J. 1878. On the structure and development of the trachea in the Indian painted snipe (Rhynchaea capensis). Proceedings of the Zoological Society of London 46:745-751.

Received 15 October 2008, accepted 11 February 2009 